\title{
Ultrafiltered Milk Reduces Bitterness in Reduced-Fat Cheddar Cheese Made with an Exopolysaccharide-Producing Culture ${ }^{1}$
}

\author{
P. Agrawal ${ }^{2}$ and A. N. Hassan ${ }^{3}$ \\ Dairy Science Department, South Dakota State University, Brookings 57007
}

\section{ABSTRACT}

The objectives were to reduce bitterness in reduced-fat Cheddar cheese made with an exopolysaccharide (EPS)producing culture and study relationships among ultrafiltration (UF), residual chymosin activity (RCA), and cheese bitterness. In previous studies, EPS-producing cultures improved the textural, melting, and viscoelastic properties of reduced-fat Cheddar cheese. However, the EPS-positive cheese developed bitterness after 2 to 3 mo of ripening due to increased RCA. We hypothesized that the reduced amount of chymosin needed to coagulate UF milk might result in reduced RCA and bitterness in cheese. Reduced-fat Cheddar cheeses were manufactured with EPS-producing and nonproducing cultures using skim milk or UF milk $(1.2 \times)$ adjusted to a casein:fat ratio of 1.35. The EPS-producing culture increased moisture and RCA in reduced-fat Cheddar cheese. Lower RCA was found in cheese made from UF milk compared with that in cheese made from control milk. Ultrafiltration at a low concentration rate $(1.2 \times)$ produced EPSpositive, reduced-fat cheese with similar RCA to that in the EPS-negative cheese. Slower proteolysis was observed in UF cheeses compared with non-UF cheeses. Panelists reported that UF EPS-positive cheese was less bitter than EPS-positive cheese made from control milk. This study showed that UF at a low concentration factor $(1.2 \times)$ could successfully reduce bitterness in cheese containing a high moisture level. Because this technology reduced the RCA level (per $g$ of protein) to a level similar to that in the control cheeses, the contribution of chymosin to cheese proteolysis would be similar in both cheeses.

Key words: reduced-fat Cheddar cheese, exopolysaccharide, ultrafiltration, bitterness

\footnotetext{
Received January 23, 2007.

Accepted March 8, 2007.

${ }^{1}$ Published with the approval of the director of the South Dakota Agricultural Experiment Station as Publication Number 3597 of the Journal Series. This research was supported in part by South Dakota Agricultural Experiment Station.

${ }^{2}$ Current address: Morningstar Foods, Gustine, CA.

${ }^{3}$ Corresponding author: Ashraf.Hassan@sdstate.edu
}

\section{INTRODUCTION}

Increasing awareness about health has led to an increase in the demand for low-fat dairy products. Reduced-fat Cheddar cheese should contain not less than $19.2 \%$ total fat and not more than $22.9 \%$ total fat and 49\% moisture (USDA, 1993).

Reduced-fat cheeses typically have poor body and texture, flavor, and functional properties. However, consumers expect to have all the characteristics of full-fat cheese in the reduced-fat counterpart. To improve the texture of reduced-fat cheese, moisture must be increased (Mistry, 2001). Methods to increase moisture include reducing the cooking temperature and time, curd washing, draining whey at higher $\mathrm{pH}$, milling at higher $\mathrm{pH}$, reducing rate of salting, and using special starter cultures and additives. However, such modifications in the traditional cheese-making protocol influence the biochemical and microbiological changes that control flavor and texture development (Banks, 2004; Mistry, 2001).

Some strains of lactic acid bacteria produce exopolysaccharides (EPS) that can improve the viscosity and texture of fermented dairy products (Hassan et al., 1996a,b; Laws and Marshall, 2001). In previous studies (Awad et al., 2005a; Hassan et al., 2005), a ropy strain of Lactococcus lactis ssp. cremoris (JFR1) increased moisture retention and improved the textural, melting, and viscoelastic properties of reduced-fat Cheddar cheese. Furthermore, this strain produced reduced-fat cheese with similar moisture in the nonfat substance (MNFS) to that in the full-fat cheese. However, this cheese developed bitterness after 2 to 3 mo of ripening due to increased residual chymosin activity (RCA; Awad et al., 2005a).

Ultrafiltration is a molecular sieving, pressure-driven membrane separation process that allows molecules with molecular weights less than 10,000 to pass through the membrane along with water, while fat, protein, and insoluble salts are retained (Shannon, 1987). Ultrafiltration was introduced to increase yield by incorporating whey proteins in cheese. It gives better control of the cheese-making process leading to optimized and uniform quality. Cost benefits of UF are associated with using less starter, rennet, salt, and color, as well as reduced 
transportation costs of cheese milk (Kosikowski, 1973). Because less chymosin is needed to coagulate UF milk (Kosikowski, 1973), we hypothesized that making cheese from UF milk may result in reduced RCA and bitterness typically associated with reduced-fat cheese made with EPS-producing cultures. The objective of this study was to improve the flavor of reduced-fat Cheddar cheese made with UF milk and an EPS-producing culture.

\section{MATERIALS AND METHODS}

\section{Cultures}

The EPS-producing culture used in this study was a ropy strain of Lactococcus lactis ssp. cremoris (JFR1; Hassan et al., 2003). This strain was maintained at $-80^{\circ} \mathrm{C}$ in $11 \%$ sterile reconstituted skim milk containing $20 \%$ (vol/vol) glycerol. The culture was grown in M17 broth (Becton Dickinson and Co., Sparks, MD), supplemented with $0.5 \%$ (wt/vol) lactose, and incubated overnight at $32^{\circ} \mathrm{C}$. Subculturing $(1 \% \mathrm{vol} / \mathrm{vol})$ was done 3 times before transfer to $11 \%$ reconstituted skim milk for overnight incubation to produce the cheese starter culture. Chr. Hansen (Milwaukee, WI) provided the nonEPS-producing culture (DVS 850).

\section{Milk Processing and Cheese Making}

Raw milk was obtained from the Dairy Research and Training Facility at South Dakota State University and separated (model \#392, Separators Inc., Indianapolis, IN) into cream (30 to $35 \%$ fat) and skim milk. Cream was pasteurized at $65^{\circ} \mathrm{C}$ for $30 \mathrm{~min}$ in a steam chest (Meyer-Blanke Co., St. Louis, MO), cooled to $<15^{\circ} \mathrm{C}$, and stored at 4 to $5^{\circ} \mathrm{C}$ until the following day. Skim milk was either pasteurized at $63^{\circ} \mathrm{C}$ for 30 min or ultrafiltered $(1.2 \times)$ at $55^{\circ} \mathrm{C}$ using a spiral wound membrane (model 1/1; Koch Membrane Systems Inc., Wilmington, MA) and then pasteurized at $63^{\circ} \mathrm{C}$ for $30 \mathrm{~min}$. The pasteurized milk or UF retentate was stored at 4 to $5^{\circ} \mathrm{C}$ and used for making cheese the following day. Three replicates of the following 5 treatments were made: 1 ) RFC: reducedfat cheese made using a blend of cream and skim milk standardized to a CN:fat ratio of 1.35 and the commercial non-EPS-producing starter culture (DVS 850; 0.032\% $\mathrm{wt} / \mathrm{wt}$ ); 2) RF-JFR: reduced-fat cheese made using a blend of cream and skim milk standardized to a CN:fat ratio of 1.35 and the ropy strain, L. lactis ssp. cremoris JFR1 ( $2 \% \mathrm{vol} / \mathrm{wt}) ; 3)$ UFC: reduced-fat cheese made using a blend of cream and UF retentate standardized to a CN:fat ratio of 1.35 and the commercial non-EPSproducing starter culture (DVS 850;0.032\% wt/wt); 4) UF-JFR: reduced-fat cheese made using a blend of cream and UF retentate standardized to a $\mathrm{CN}$ :fat ratio of 1.35 and the ropy strain L. lactis ssp. cremoris JFR1
(2\% vol/wt); and 5) FFC: full-fat cheese made using a blend of cream and skim milk standardized to a CN:fat ratio of 0.7 and the commercial non-EPS-producing Cheddar cheese starter culture (DVS 850; 0.032\% wt/ wt). Cheese milk (100 kg) was assigned to a double-O cheese vat (Kusel Equipment Co., Watertown, WI) and the temperature was adjusted to $31^{\circ} \mathrm{C}$. The amount of culture was selected, based on a preliminary experiment, to give similar acidification rates and cheese-making times $(\sim 5 \mathrm{~h})$ in all treatments.

Culture was added to milk at $31^{\circ} \mathrm{C}$, which was then ripened until the $\mathrm{pH}$ dropped by 0.1 units. Chymosin (Chymax, Chr. Hansen) was added at $12 \mathrm{~mL} / 100 \mathrm{~kg}$ for control milk and $7.2 \mathrm{~mL} / 100 \mathrm{~kg}$ for UF milk. The coagulum was cut upon reaching optimum firmness in 25 to 30 min using $0.95-\mathrm{cm}$ wire knives in a circular motion. Cooking was done by raising the temperature to $39^{\circ} \mathrm{C}$ in $30 \mathrm{~min}$ and holding at this temperature for $30 \mathrm{~min}$. Whey was drained at the end of cooking, and the curd was cheddared until a $\mathrm{pH}$ value of 5.4 was attained, and then milled. Salting was done with dry, food-grade fine salt (Morton salt, Chicago, IL) at $2 \%$ by weight in 3 equal applications over $15 \mathrm{~min}$. Curd was hooped in rectangular blocks, pressed overnight at 2.5 $\mathrm{kg} / \mathrm{cm}^{2}$ (AFVS-Spec, Kusel Equipment Co.), vacuum packed, and ripened at $4^{\circ} \mathrm{C}$ for 6 mo.

\section{Chemical Composition of Cheese}

Cheeses ( $1 \mathrm{~d}$ old) were analyzed for moisture by the oven method (method 926.08; AOAC, 2003), fat by the Mojonnier method (method 933.05; AOAC, 2003), salt by chloride analyzer (model 926, Nelson Jameson Inc., Marshfield, WI), and total protein by macro-Kjeldahl (method 920.123; AOAC, 2003).

\section{Microbiological Analysis}

Cheese samples were analyzed for numbers of lactic acid bacteria $(\mathbf{L A B})$ at the 4 ripening periods $(1 \mathrm{~d}$, and $1,3$, and $6 \mathrm{mo})$. Shredded cheese samples (10 g) were homogenized with $90 \mathrm{~mL}$ of sterile $2 \%$ sodium citrate solution in a laboratory stomacher (Seward Stomacher Circulator 400, Norfolk, UK). Serial dilutions were prepared in sterile $0.05 \%$ peptone. Appropriate dilutions were pour-plated in duplicate with M17 agar supplemented with $0.5 \%$ lactose. Plates were incubated at $25^{\circ} \mathrm{C}$ for $48 \mathrm{~h}$.

\section{Determination of RCA}

The RCA in 1-d-old cheese samples was determined according to Awad et al. (2005a) using a Varian Prostar HPLC (Varian Inc., Walnut Creek, CA) equipped with 
Table 1. Composition of milk used in making reduced- and full-fat Cheddar cheeses ${ }^{1}$

\begin{tabular}{lcccccc}
\hline & \multicolumn{5}{c}{ Treatment $^{2}$} \\
Parameter & RFC & RF-JFR & UFC & UF-JFR & FFC & SEM \\
\hline TS, \% & $11.3^{\mathrm{c}}$ & $11.2^{\mathrm{c}}$ & $11.8^{\mathrm{b}}$ & $11.8^{\mathrm{b}}$ & $12.5^{\mathrm{a}}$ & 0.08 \\
Fat, \% & $1.90^{\mathrm{c}}$ & $1.90^{\mathrm{c}}$ & $2.20^{\mathrm{b}}$ & $2.20^{\mathrm{b}}$ & $3.60^{\mathrm{a}}$ & 0.01 \\
CN:fat ratio & $1.37^{\mathrm{a}}$ & $1.37^{\mathrm{a}}$ & $1.34^{\mathrm{a}}$ & $1.34^{\mathrm{a}}$ & $0.71^{\mathrm{b}}$ & 0.02 \\
pH & $6.62^{\mathrm{a}}$ & $6.62^{\mathrm{a}}$ & $6.62^{\mathrm{a}}$ & $6.62^{\mathrm{a}}$ & $6.61^{\mathrm{a}}$ & 0.01 \\
\hline
\end{tabular}

${ }^{\mathrm{a}-\mathrm{c}}$ Means in the same row without common superscripts are different $(P \leq 0.05)$.

${ }^{1}$ Mean of 3 replicates.

${ }^{2} \mathrm{RFC}=$ reduced-fat control made with a non-EPS-producing culture; RF-JFR $=$ reduced-fat cheese made with the ropy culture Lactococcus lactis ssp. cremoris JFR1; UFC = reduced-fat control made from $1.2 \times$ UF milk and a non-EPS-producing culture; UF-JFR = reduced-fat cheese made from $1.2 \times$ UF milk and the ropy culture Lactococcus lactis ssp. cremoris JFR1; and FFC = full-fat control made with a non-EPS-producing culture.

a RP-C18 Lichrospher analytical column $(250 \times 4.6 \mathrm{~mm}$, 5 um; Perkin-Elmer, Norwalk, CT).

\section{Water-Soluble Nitrogen and TCA-Soluble Nitrogen}

Water-soluble nitrogen (WSN) and TCA-soluble nitrogen (TCA-SN) were determined at 4 ripening periods (1 d, and 1, 3, and 6 mo) as described by Ardö (1999).

\section{Free Amino Groups}

The Cd-ninhydrin method (Folkertsma and Fox, 1992) was used to measure the free amino groups at 4 ripening periods ( $1 \mathrm{~d}$, and 1,3 , and $6 \mathrm{mo}$ ).

\section{Sensory Evaluation}

A panel of 4 experienced judges from the Dairy Science Department, South Dakota State University (Brookings) evaluated 5 cheese samples for flavor characteristics at 3 and 6 mo of ripening. Sample preparation and evaluation was done as described by Awad et al. (2005b). Coded samples were randomly presented. Flavor attributes were recorded on a 1-to-9 scale, where $1=$ none, $5=$ definite, and $9=$ pronounced. Overall flavor scores were $1=$ poor, $5=$ average, and $9=$ excellent.

\section{Statistical Analyses}

The data were analyzed by ANOVA using the GLM procedure (SAS Institute, 1999). Duncan's multiple range test was used to compare means, and differences were considered significant at $P \leq 0.05$.

\section{RESULTS AND DISCUSSION}

\section{Composition of Milk}

Table 1 presents composition of cheese milks. Full-fat milk had the highest $(P \leq 0.05)$ TS followed by UF milk, whereas regular reduced-fat milk contained the lowest $(P \leq 0.05)$ level of TS. The CN content of UF milk was higher $(P \leq 0.05)$ than that in non-UF milk. The CN:fat ratio was adjusted to $\sim 1.35$ (reduced-fat and UF milk) and 0.7 (full-fat milk). The $\mathrm{pH}$ of milk used in this study was $\sim 6.62$ and was similar $(P \geq 0.05)$ in all milks.

\section{Composition of Cheese, RCA, and $\mathrm{pH}$}

The reduction in fat level in cheese milk resulted in an increase $(P \leq 0.05)$ in cheese moisture and protein and a decrease in fat in the DM, and salt-in-moisture (Table 2). Similar results have been reported by Fenelon and Guinee (1999), Fenelon et al. (2000), and Awad et al. (2005a). Cheeses made with L. lactis ssp. cremoris (UF-JFR and RF-JFR) had higher $(P \leq 0.05)$ moisture and MNFS than did those made with the commercial non-EPS-producing starter culture (Table 2). This increase in moisture was due to the ability of EPS to bind water (Awad et al., 2005a). The use of JFR1, with or without UF, produced reduced-fat cheeses with similar MNFS to that in the full-fat type without the need for modifying the cheese-making procedure used in making full-fat cheese. Awad et al. (2005a) reported a similar effect of JFR1 in reduced-fat Cheddar cheese made from regular milk.

The EPS-negative reduced-fat cheese made from UF milk (UFC) had higher $(P \leq 0.05)$ moisture than did cheese made from regular milk (RFC; Table 2). McGregor and White (1990) also reported higher moisture in reduced-fat Cheddar cheese made from UF milk than in cheese made from regular milk. Marshall (1982) reported that concentration by UF decreased the rate of curd syneresis, which leads to higher moisture retention. The CN content of UF milks was higher $(P \leq 0.05)$ than that in regular milks (data not shown). The higher the $\mathrm{CN}$ content, the firmer the coagulum if the temperature, calcium ion activity, time, and $\mathrm{pH}$ of the coagulation remain constant (Green and Grandison, 1993). Johnson 
Table 2. Chemical composition and residual chymosin activity of reduced- and full-fat Cheddar cheeses ${ }^{1}$

\begin{tabular}{lcccccc}
\hline & \multicolumn{5}{c}{ Treatment $^{3}$} \\
\cline { 2 - 5 } Parameter $^{2}$ & RFC & RF-JFR & UFC & UF-JFR & FFC & SEM \\
\hline Protein, \% & $31.1^{\mathrm{a}}$ & $29.0^{\mathrm{bc}}$ & $30.1^{\mathrm{ab}}$ & $28.1^{\mathrm{c}}$ & $23.1^{\mathrm{d}}$ & 0.48 \\
Fat, \% & $21.0^{\mathrm{b}}$ & $19.2^{\mathrm{c}}$ & $20.5^{\mathrm{b}}$ & $18.8^{\mathrm{c}}$ & $32.6^{\mathrm{a}}$ & 0.12 \\
Moisture, \% & $43.2^{\mathrm{c}}$ & $47.3^{\mathrm{a}}$ & $44.8^{\mathrm{b}}$ & $48.0^{\mathrm{a}}$ & $40.5^{\mathrm{d}}$ & 0.27 \\
Salt, \% & $1.63^{\mathrm{a}}$ & $1.61^{\mathrm{a}}$ & $1.60^{\mathrm{ab}}$ & $1.57^{\mathrm{b}}$ & $1.55^{\mathrm{b}}$ & 0.01 \\
FDM & $36.9^{\mathrm{b}}$ & $36.6^{\mathrm{bc}}$ & $37.1^{\mathrm{b}}$ & $36.2^{\mathrm{c}}$ & $54.7^{\mathrm{a}}$ & 0.20 \\
MNFS & $54.7^{\mathrm{c}}$ & $58.6^{\mathrm{a}}$ & $56.4^{\mathrm{b}}$ & $59.1^{\mathrm{a}}$ & $60.0^{\mathrm{a}}$ & 0.32 \\
SM & $3.7^{\mathrm{b}}$ & $3.4^{\mathrm{c}}$ & $3.5^{\mathrm{c}}$ & $3.3^{\mathrm{d}}$ & $4.0^{\mathrm{a}}$ & 0.01 \\
RCA & $20.4^{\mathrm{b}}$ & $25.2^{\mathrm{a}}$ & $14.5^{\mathrm{d}}$ & $18.2^{\mathrm{c}}$ & $21.6^{\mathrm{b}}$ & 0.51 \\
RCA/g of protein & $0.07^{\mathrm{b}}$ & $0.09^{\mathrm{a}}$ & $0.05^{\mathrm{c}}$ & $0.07^{\mathrm{b}}$ & $0.09^{\mathrm{a}}$ & 0.00 \\
\hline
\end{tabular}

${ }^{\mathrm{a}-\mathrm{d}}$ Means in the same row without common superscripts are different $(P \leq 0.05)$.

${ }^{1}$ Mean of 3 replicates.

${ }^{2} \mathrm{FDM}$ = fat in DM; MNFS = moisture in nonfat substance; $\mathrm{SM}$ = salt-in-moisture; $\mathrm{RCA}$ = residual chymosin activity, rennet activity units/kg of cheese.

${ }^{3} \mathrm{RFC}=$ reduced-fat control made with a non-EPS-producing culture; RF-JFR = reduced-fat cheese made with the ropy culture Lactococcus lactis ssp. cremoris JFR1; UFC = reduced-fat control made from $1.2 \times$ UF milk and a non-EPS-producing culture; UF-JFR = reduced-fat cheese made from $1.2 \times$ UF milk and the ropy culture Lactococcus lactis ssp. cremoris JFR1; and FFC = full-fat control made with a non-EPS-producing culture.

et al. (2001) reported that a firmer coagulum at cutting increased the cheese moisture. Also, whey proteins might undergo shear denaturation during UF (Lelievre and Lawrence, 1988), which increases water-binding capacity (Mistry, 2004). Because the time needed to achieve $1.2 \times$ concentration by UF was short ( $10 \mathrm{~min})$, shear denaturation of whey proteins might be minimal. The increase in moisture associated with UF was not observed in EPS-positive cheeses. This might be due to the lower EPS:protein ratio in UF cheese, because the amount of culture used in making RF-JFR and UF-JFR was the same, which offsets the increase in moisture caused by UF.

In FFC, the RCA was 21.6 rennet activity units/kg of cheese (Table 2). The activity was slightly higher than that reported by Awad et al. (2005a). This could be due to the higher moisture content of FFC in our study (40.5 vs. $39.7 \%)$. The RCA in RF-JFR (25.2 rennet activity units/kg of cheese) was higher $(P \leq 0.05)$ than that in FFC (21.6 rennet activity units/kg of cheese) and RFC (20.4 rennet activity units/kg of cheese). The residual activity is dependent on the type of enzyme, manufacturing conditions, and the final moisture content of cheese (Farkye, 1995). Because the manufacturing conditions were same in all treatments and there were no differences $(P \geq 0.05)$ in $\mathrm{pH}$ at $\mathrm{d} 1$ of manufacture among all cheeses (data not shown), the differences in the RCA could be related to the differences in the moisture content of cheeses. Similar results were reported by Awad et al. (2005a). The reduced amount of chymosin needed to coagulate UF milks resulted in lower $(P \leq 0.05)$ chymosin activity in the resulting cheeses than in cheeses made from regular milk (Table 2$)$. The higher $(P \leq 0.05)$
RCA in UF-JFR compared with UFC is associated with higher moisture in the UF-JFR cheese. The combined effect of UF (1.2×) and JFR1 produced reduced-fat Cheddar cheese with similar RCA levels (per g of protein) to that in the EPS-negative RFC. This finding indicated that UF at the low concentration factor was successfully used to decrease RCA in reduced-fat cheeses containing high moisture to levels similar to those in cheeses with much lower moisture contents.

There were no differences $(P \geq 0.05)$ in $\mathrm{pH}$ (5.1 to 5.2) among all cheeses after $1 \mathrm{~d}$ of manufacture (data not shown). During the first month of ripening, the $\mathrm{pH}$ decreased in all cheeses. The greatest reduction in $\mathrm{pH}$ was observed in RF-JFR, UF-JFR, and FFC cheeses, which contained the highest MNFS levels. Similar results were reported by Awad et al. (2005a). Generally, the $\mathrm{pH}$ of all cheeses increased between the first and third month of ripening. This might be due to the formation of alkaline nitrogenous compounds during protein breakdown (Fox and McSweeney, 1996). After 3 mo of ripening, $\mathrm{pH}$ remained unchanged or declined slightly, probably due to accumulation of acids (Acharya and Mistry, 2004). The $\mathrm{pH}$ of cheese was not affected by UF at $1.2 \times(P$ $>0.05$ ).

\section{Viability of Starter Culture in Cheese During Ripening}

Changes in $\mathrm{LAB}$ counts during ripening are given in Table 3 . At $d 1$, cheeses made with JFR1 had the highest $(P \leq 0.05)$ counts of LAB. The LAB count in UFC was higher $(P \leq 0.05)$ than that in RFC. The high bacterial count seemed to be associated with higher moisture. 
Table 3. Counts of lactic acid bacteria (log cfu/g of cheese) in reduced- and full-fat Cheddar cheeses during ripening ${ }^{1}$

\begin{tabular}{lcccccc}
\hline & \multicolumn{5}{c}{ Treatment $^{2}$} \\
\cline { 2 - 6 } Ripening time & RFC & RF-JFR & UFC & UF-JFR & FFC & SEM \\
\hline $1 \mathrm{~d}$ & $7.3^{\mathrm{c}, \mathrm{A}}$ & $8.9^{\mathrm{a} . \mathrm{A}}$ & $7.9^{\mathrm{b}, \mathrm{A}}$ & $9.3^{\mathrm{a}, \mathrm{A}}$ & $7.7^{\mathrm{bc}, \mathrm{A}}$ & 0.14 \\
$1 \mathrm{mo}$ & $6.8^{\mathrm{c}, \mathrm{B}}$ & $8.7^{\mathrm{a}, \mathrm{A}}$ & $7.3^{\mathrm{b}, \mathrm{A}}$ & $8.3^{\mathrm{a}, \mathrm{B}}$ & $6.8^{\mathrm{b}, \mathrm{B}}$ & 0.17 \\
$3 \mathrm{mo}$ & $4.9^{\mathrm{b}, \mathrm{C}}$ & $7.6^{\mathrm{a}, \mathrm{B}}$ & $4.6^{\mathrm{b}, \mathrm{B}}$ & $7.4^{\mathrm{a}, \mathrm{C}}$ & $4.9^{\mathrm{b}, \mathrm{C}}$ & 0.11 \\
6 mo & $4.3^{\mathrm{b}, \mathrm{D}}$ & $6.8^{\mathrm{a}, \mathrm{C}}$ & $4.5^{\mathrm{bc}, \mathrm{B}}$ & $6.9^{\mathrm{a}, \mathrm{D}}$ & $4.8^{\mathrm{b}, \mathrm{C}}$ & 0.14 \\
\hline
\end{tabular}

${ }^{\mathrm{a}-\mathrm{c}}$ Means in the same row without common superscripts are different $(P \leq 0.05)$.

${ }^{\mathrm{A}-\mathrm{D}}$ Means in the same column without common subscripts are different $(P \leq 0.05)$.

${ }^{1}$ Mean of 3 replicates.

${ }^{2} \mathrm{RFC}=$ reduced-fat control made with a non-EPS-producing culture; RF-JFR = reduced-fat cheese made with the ropy culture Lactococcus lactis ssp. cremoris JFR1; UFC = reduced-fat control made from $1.2 \times \mathrm{UF}$ milk and a non-EPS-producing culture; UF-JFR = reduced-fat cheese made from $1.2 \times$ UF milk and the ropy culture Lactococcus lactis ssp. cremoris JFR1; and FFC = full-fat control made with a non-EPS-producing culture.

During ripening, there was a gradual decrease in the population of $\mathrm{LAB}$ in all cheeses, resulting in reductions of approximately 2 (in cheese made with the EPS-positive culture) to 3 (in cheese made with the commercial EPS-negative culture) logs after 6 mo. Similar results have been previously reported by Sallami et al. (2004) and Dabour et al. (2006), who found that counts of LAB reached a maximum during or shortly after Cheddar cheese manufacture. During ripening, RF-JFR and UFJFR maintained higher $(P \leq 0.05)$ counts of LAB than did all other cheeses. This might be due to the higher moisture and lower salt-in-moisture in these cheeses than in all other cheeses. Also, autolysis seems to occur at a slower rate in the EPS-positive than in the commercial EPS-negative culture as the former culture showed a $2 \log$ reduction in numbers compared with a $3 \log$ reduction in the commercial cultures during cheese ripening.

\section{Proteolysis During Ripening}

WSN. The WSN signifies proteins (excluding most caseins), all peptides, AA, and smaller $\mathrm{N}$ compounds such as amines, urea, and ammonium (Ardö, 1999). Levels of WSN expressed as a percentage of either total N (WSN\%TN) or cheese weight increased $(P \leq 0.05)$ in all cheeses during ripening (Table 4). Similar results were reported by Sallami et al. (2004), Awad et al. (2005a), and Dabour et al. (2006). At d 1, WSN\%TN was highest $(P \leq 0.05)$ in FFC and lowest $(P \leq 0.05)$ in UF cheeses. After 1 mo of ripening, FFC had the highest $(P \leq 0.05)$ level of WSN\%TN followed by EPS-positive reduced-fat cheeses (RF-JFR and UF-JFR), whereas EPS-negative reduced-fat cheeses (RFC and UFC) contained the lowest $(P \leq 0.05)$ levels of WSN\%TN. The high WSN in FFC, RF-JFR, and UF-JFR was associated with high MNFS and RCA levels, which induce proteolysis (Visser, 1993;
Awad et al., 2005a). There was no difference $(P \geq 0.05)$ in levels of WSN\%TN between UF and non-UF cheeses at $1 \mathrm{mo}$ of ripening. However, at $3 \mathrm{mo}$ of ripening, UF cheeses contained lower $(P \leq 0.05)$ levels of WSN\%TN than did the non-UF cheeses (Table 4). Slower proteolysis in UF cheeses has also been reported by Green et al. (1981), Hickey et al. (1983), and Creamer et al. (1987). It seems that the initial increase in the level of WSN\%TN in the EPS-positive cheese was caused by the high RCA. However, the higher level of WSN\%TN in the aged RFC cheese made with the commercial starter culture than that in cheese made with the EPS-positive culture indicates a better proteolytic system in the former culture.

TCA-SN. Trichloroacetic acid-soluble N measures medium-sized to small peptides, AA, and smaller N compounds, such as amines, urea, and ammonium compounds (Ardö, 1999). Chymosin and starter peptidases are responsible for the production of TCA-SN (McSweeney and Fox, 1993). Levels of TCA-SN expressed as a percentage of either total $\mathrm{N}$ or cheese weight increased $(P \leq 0.05)$ in all cheeses during ripening (Table $5)$. Similar results were reported by O'Keeffe et al. (1978). Generally, aged reduced-fat UF cheeses maintained lower levels of TCA-SN than did cheeses made from regular milk (Table 5). This suggested slower proteolysis in UF cheeses. Furthermore, aged reduced-fat cheeses made with the commercial culture contained higher levels of TCA-SN than did the corresponding cheeses made with the EPS-producing culture, indicating a better proteolytic system in the former culture.

Free Amino Groups. Concentrations of free amino groups (expressed as mg of Leu/g of cheese) at different ripening periods are summarized in Table 6. Generally, the concentration of free amino groups increased $(P \leq$ $0.05)$ as ripening progressed. In EPS-positive cheeses (RF-JFR and UF-JFR), no increase was found in levels of free amino groups during the first month of ripening 
Table 4. Water-soluble nitrogen (WSN) as a percentage of total nitrogen (WSN\%TN) and cheese weight (WSN\%CW) in reduced- and full-fat Cheddar cheeses during ripening ${ }^{1}$

\begin{tabular}{lcrrrrr}
\hline & \multicolumn{5}{c}{ Treatment $^{2}$} \\
\cline { 2 - 5 } Ripening time & \multicolumn{1}{c}{ RFC } & RF-JFR & UFC & UF-JFR & FFC & SEM \\
\hline WSN\%TN & $3.71^{\mathrm{c}, \mathrm{D}}$ & $3.92^{\mathrm{b}, \mathrm{D}}$ & $3.26^{\mathrm{d}, \mathrm{D}}$ & $3.47^{\mathrm{d}, \mathrm{D}}$ & $4.70^{\mathrm{a}, \mathrm{D}}$ & 0.11 \\
$1 \mathrm{~d}$ & $10.61^{\mathrm{c}, \mathrm{C}}$ & $11.66^{\mathrm{b}, \mathrm{C}}$ & $10.62^{\mathrm{c}, \mathrm{C}}$ & $11.69^{\mathrm{b}, \mathrm{C}}$ & $13.52^{\mathrm{a}, \mathrm{C}}$ & 0.24 \\
$1 \mathrm{mo}$ & $20.17^{\mathrm{a}, \mathrm{B}}$ & $20.11^{\mathrm{a}, \mathrm{B}}$ & $15.90^{\mathrm{b}, \mathrm{B}}$ & $16.61^{\mathrm{b}, \mathrm{B}}$ & $20.53^{\mathrm{a}, \mathrm{B}}$ & 0.26 \\
$3 \mathrm{mo}$ & $27.71^{\mathrm{a}, \mathrm{A}}$ & $25.85^{\mathrm{b}, \mathrm{A}}$ & $22.25^{\mathrm{c}, \mathrm{A}}$ & $22.3^{\mathrm{c}, \mathrm{A}}$ & $28.60^{\mathrm{a}, \mathrm{A}}$ & 0.37 \\
$6 \mathrm{mo}$ & & & & & & \\
WSN\%CW & $0.18^{\mathrm{a}, \mathrm{D}}$ & $0.18^{\mathrm{a}, \mathrm{D}}$ & $0.15^{\mathrm{b}, \mathrm{D}}$ & $0.15^{\mathrm{b}, \mathrm{D}}$ & $0.17^{\mathrm{a}, \mathrm{D}}$ & 0.005 \\
$1 \mathrm{~d}$ & $0.52^{\mathrm{a}, \mathrm{C}}$ & $0.53^{\mathrm{a}, \mathrm{C}}$ & $0.50^{\mathrm{a}, \mathrm{C}}$ & $0.51^{\mathrm{a}, \mathrm{C}}$ & $0.51^{\mathrm{a}, \mathrm{C}}$ & 0.012 \\
$1 \mathrm{mo}$ & $0.98^{\mathrm{a}, \mathrm{B}}$ & $0.92^{\mathrm{b}, \mathrm{B}}$ & $0.75^{\mathrm{c}, \mathrm{B}}$ & $0.73^{\mathrm{c}, \mathrm{B}}$ & $0.77^{\mathrm{c}, \mathrm{B}}$ & 0.017 \\
$3 \mathrm{mo}$ & $1.35^{\mathrm{a}, \mathrm{A}}$ & $1.21^{\mathrm{b}, \mathrm{A}}$ & $1.10^{\mathrm{c}, \mathrm{A}}$ & $1.00^{\mathrm{d}, \mathrm{A}}$ & $1.10^{\mathrm{c}, \mathrm{A}}$ & 0.020 \\
$6 \mathrm{mo}$ & & &
\end{tabular}

${ }^{\mathrm{a}-\mathrm{d}}$ Means in the same row without common superscripts are different $(P \leq 0.05)$.

${ }^{\mathrm{A}-\mathrm{D}}$ Means in the same column without common subscripts are different $(P \leq 0.05)$.

${ }^{1}$ Mean of 3 replicates.

${ }^{2} \mathrm{RFC}=$ reduced-fat control made with a non-EPS-producing culture; RF-JFR $=$ reduced-fat cheese made with the ropy culture Lactococcus lactis ssp. cremoris JFR1; UFC = reduced-fat control made from $1.2 \times \mathrm{UF}$ milk and a non-EPS-producing culture; UF-JFR = reduced-fat cheese made from $1.2 \times$ UF milk and the ropy culture Lactococcus lactis ssp. cremoris JFR1; and FFC = full-fat control made with a non-EPS-producing culture.

after which cheeses maintained the lowest $(P \leq 0.05)$ concentration of the free amino groups among all cheeses (Table 6). Awad et al. (2005a) also reported slower release of free amino groups in reduced-fat Cheddar cheese made with JFR1. During ripening, UFC maintained lower $(P \leq 0.05)$ concentrations of free amino groups than did RFC, indicating a slower release of free amino groups in the UF cheese. However, no differences $(P \geq 0.05)$ were found in the levels of amino groups between RFJFR and UF-JFR. Hickey et al. (1983) also reported slower release of free amino groups in UF cheeses than in non-UF cheeses. The low level of free amino groups in EPS-positive cheese compared with that in cheeses made with the commercial culture demonstrates poor peptidolytic activity in the former cheeses.

\section{Sensory Evaluation}

The results of sensory assessments are summarized in Table 7. Definite bitterness was evident in RF-JFR after 3 mo of ripening. Awad et al. (2005a) found that reduced-fat Cheddar cheese made with JFR1 showed a

Table 5. Trichloroacetic acid-soluble nitrogen (TCA-SN) as a percentage of total nitrogen (TCA\%TN) and cheese weight (TCA\%CW) in reduced- and full-fat Cheddar cheeses during ripening ${ }^{1}$

\begin{tabular}{|c|c|c|c|c|c|c|}
\hline \multirow[b]{2}{*}{ Ripening time } & \multicolumn{5}{|c|}{ Treatment $^{2}$} & \multirow[b]{2}{*}{ SEM } \\
\hline & $\mathrm{RFC}$ & RF-JFR & UFC & UF-JFR & FFC & \\
\hline \multicolumn{7}{|l|}{ TCA $\% \mathrm{TN}$} \\
\hline $1 \mathrm{~d}$ & $2.71^{\mathrm{a}, \mathrm{D}}$ & $1.98^{\mathrm{c}, \mathrm{D}}$ & $1.96^{\mathrm{c}, \mathrm{D}}$ & $1.85^{\mathrm{c}, \mathrm{D}}$ & $2.18^{\mathrm{b}, \mathrm{D}}$ & 0.06 \\
\hline $1 \mathrm{mo}$ & $6.85^{\mathrm{a}, \mathrm{C}}$ & $5.81^{\mathrm{b}, \mathrm{C}}$ & $6.04^{\mathrm{b}, \mathrm{C}}$ & $5.76^{\mathrm{b}, \mathrm{C}}$ & $7.10^{\mathrm{a}, \mathrm{C}}$ & 0.24 \\
\hline $3 \mathrm{mo}$ & $12.94^{\mathrm{a}, \mathrm{B}}$ & $9.52^{\mathrm{d}, \mathrm{B}}$ & $10.68^{\mathrm{c}, \mathrm{B}}$ & $8.86^{\mathrm{e}, \mathrm{B}}$ & $11.64^{\mathrm{b}, \mathrm{B}}$ & 0.08 \\
\hline $6 \mathrm{mo}$ & $17.26^{\mathrm{a}, \mathrm{A}}$ & $12.98^{\mathrm{c}, \mathrm{A}}$ & $15.24^{\mathrm{b}, \mathrm{A}}$ & $12.31^{\mathrm{d}, \mathrm{A}}$ & $17.54^{\mathrm{a}, \mathrm{A}}$ & 0.18 \\
\hline \multicolumn{7}{|l|}{ TCA\%CW } \\
\hline $1 \mathrm{~d}$ & $0.13^{\mathrm{a}, \mathrm{D}}$ & $0.09^{\mathrm{b}, \mathrm{D}}$ & $0.09^{b, D}$ & $0.08^{\mathrm{b}, \mathrm{D}}$ & $0.09^{\mathrm{b}, \mathrm{D}}$ & 0.005 \\
\hline $1 \mathrm{mo}$ & $0.33^{\mathrm{a}, \mathrm{C}}$ & $0.26^{\text {bc,C }}$ & $0.29^{b, C}$ & $0.25^{\mathrm{c}, \mathrm{C}}$ & $0.27^{\mathrm{bc}, \mathrm{C}}$ & 0.011 \\
\hline $3 \mathrm{mo}$ & $0.63^{\mathrm{a}, \mathrm{B}}$ & $0.43^{\mathrm{c}, \mathrm{B}}$ & $0.50^{\mathrm{b}, \mathrm{B}}$ & $0.39^{\mathrm{d}, \mathrm{B}}$ & $0.44^{\mathrm{c}, \mathrm{B}}$ & 0.005 \\
\hline $6 \mathrm{mo}$ & $0.85^{\mathrm{a}, \mathrm{A}}$ & $0.60^{\mathrm{d}, \mathrm{A}}$ & $0.74^{\mathrm{b}, \mathrm{A}}$ & $0.55^{\mathrm{e}, \mathrm{A}}$ & $0.66^{\mathrm{c}, \mathrm{A}}$ & 0.005 \\
\hline
\end{tabular}

${ }^{\mathrm{a}-\mathrm{e}}$ Means in the same row without common superscripts are different $(P \leq 0.05)$.

${ }^{\mathrm{A}-\mathrm{D}}$ Means in the same column without common subscripts are different $(P \leq 0.05)$.

${ }^{1}$ Mean of 3 replicates.

${ }^{2} \mathrm{RFC}=$ reduced-fat control made with a non-EPS-producing culture; RF-JFR = reduced-fat cheese made with the ropy culture Lactococcus lactis ssp. cremoris JFR1; UFC = reduced-fat control made from $1.2 \times \mathrm{UF}$ milk and a non-EPS-producing culture; UF-JFR = reduced-fat cheese made from $1.2 \times$ UF milk and the ropy culture Lactococcus lactis ssp. cremoris JFR1; and FFC = full-fat control made with a non-EPS-producing culture. 
Table 6. Concentration of free amino groups (mg of leucine/g of cheese) in reduced- and full-fat Cheddar cheeses during ripening ${ }^{1}$

\begin{tabular}{lcccccc}
\hline & \multicolumn{5}{c}{ Treatment $^{2}$} \\
\cline { 2 - 5 } Ripening time & RFC & RF-JFR & UFC & UF-JFR & FFC & SEM \\
\hline $1 \mathrm{~d}$ & $0.060^{\mathrm{a}, \mathrm{D}}$ & $0.049^{\mathrm{b}, \mathrm{C}}$ & $0.059^{\mathrm{a}, \mathrm{D}}$ & $0.046^{\mathrm{c}, \mathrm{C}}$ & $0.033^{\mathrm{d}, \mathrm{D}}$ & 0.001 \\
$1 \mathrm{mo}$ & $0.153^{\mathrm{a}, \mathrm{C}}$ & $0.052^{\mathrm{d}, \mathrm{C}}$ & $0.084^{\mathrm{c}, \mathrm{C}}$ & $0.050^{\mathrm{d}, \mathrm{C}}$ & $0.112^{\mathrm{b}, \mathrm{C}}$ & 0.007 \\
$3 \mathrm{mo}$ & $0.412^{\mathrm{a}, \mathrm{B}}$ & $0.084^{\mathrm{d}, \mathrm{B}}$ & $0.319^{\mathrm{b}, \mathrm{B}}$ & $0.079^{\mathrm{d}, \mathrm{B}}$ & $0.186^{\mathrm{c}, \mathrm{B}}$ & 0.020 \\
$6 \mathrm{mo}$ & $0.525^{\mathrm{a}, \mathrm{A}}$ & $0.107^{\mathrm{c}, \mathrm{A}}$ & $0.407^{\mathrm{b}, \mathrm{A}}$ & $0.115^{\mathrm{c}, \mathrm{A}}$ & $0.359^{\mathrm{b}, \mathrm{A}}$ & 0.013 \\
\hline
\end{tabular}

${ }^{\mathrm{a}-\mathrm{d}}$ Means in the same row without common superscripts are different $(P \leq 0.05)$.

${ }^{\mathrm{A}-\mathrm{D}}$ Means in the same column without common subscripts are different $(P \leq 0.05)$.

${ }^{1}$ Mean of 3 replicates.

${ }^{2} \mathrm{RFC}=$ reduced-fat control made with a non-EPS-producing culture; RF-JFR = reduced-fat cheese made with the ropy culture Lactococcus lactis ssp. cremoris JFR1; UFC = reduced-fat control made from $1.2 \times \mathrm{UF}$ milk and a non-EPS-producing culture; UF-JFR = reduced-fat cheese made from $1.2 \times$ UF milk and the ropy culture Lactococcus lactis ssp. cremoris JFR1; and FFC = full-fat control made with a non-EPS-producing culture.

more significant reduction in the level of $\beta$ - $\mathrm{CN}$, one of the main sources for bitter peptides, than did cheese made with the commercial starter culture used in this study. Furthermore, cheese made with JFR 1 contained higher levels of high-molecular-weight and hydrophobic peptides than did cheese made with the commercial culture (Awad et al., 2005a). Such peptides, which produce bitterness, are accumulated in cheese as a result of high RCA and weak peptidolytic activity of the cheese starter culture (Lemieux and Simard, 1992; Awad et al., 2005a). The RF-JFR cheese contained high RCA and the JFR1 strain seems to have a poor peptidolytic activity compared with the commercial starter culture, as shown in Tables 2, 4, 5, and 6. However, bitterness was reduced in 3-mo-old cheese made with JFR1 when UF milk was used (UF-JFR). Because RF-JFR and UF-JFR did not differ in composition, $\mathrm{pH}$, starter culture used, or bacterial count, the reduction in bitterness of UF-JFR cheese could be directly related to lowering the level of RCA. Spangler et al. (1990) observed increased bitterness with increasing rennet concentration.
After 6-mo of ripening, UF-JFR was less $(P \leq 0.05)$ bitter than RF-JFR, although both cheeses were definitely bitter. Although UF-JFR contained lower RCA than RFC, definite bitterness was detected only in the former cheeses (UF-JFR). This is because of the ability of the culture used in RFC to hydrolyze the high-molecularweight hydrophobic peptides (Awad et al., 2005a).

No or very slight bitterness was detected in cheeses made with the commercial cultures even after 6 mo of ripening. Slight to definite acid was detected in all cheeses.

In conclusion, bitterness in the EPS-positive cheese was due to high RCA activity associated with high moisture and a weak peptidolytic system in the EPS-producing culture used in this study. Ultrafiltration at a low concentration level $(1.2 \times)$ lowered the RCA, resulting in reduced bitterness in the EPS-positive cheese. The use of EPS-producing cultures with good peptidolytic activity combined with low-concentration UF might remove bitterness from reduced-fat cheeses containing high moisture levels.

Table 7. Flavor scores for reduced- and full-fat Cheddar cheeses during ripening ${ }^{1}$

\begin{tabular}{lccccccr}
\hline & \multirow{7}{*}{$\begin{array}{c}\text { Ripening } \\
\text { time }(\mathrm{mo})\end{array}$} & RFC & RF-JFR & UFC & UF-JFR & FFC & SEM \\
\cline { 3 - 7 } Attribute $^{2}$ & 3 & $4.3^{\mathrm{ab}, \mathrm{A}}$ & $4.9^{\mathrm{a}, \mathrm{A}}$ & $3.3^{\mathrm{b}, \mathrm{A}}$ & $4.5^{\mathrm{ab}, \mathrm{A}}$ & $4.8^{\mathrm{a}, \mathrm{A}}$ & 0.41 \\
\hline \multirow{2}{*}{ Sour taste intensity } & 6 & $4.9^{\mathrm{ab}, \mathrm{A}}$ & $4.6^{\mathrm{ab}, \mathrm{A}}$ & $4.5^{\mathrm{ab}, \mathrm{A}}$ & $4.4^{\mathrm{b}, \mathrm{A}}$ & $5.3^{\mathrm{a}, \mathrm{A}}$ & 0.27 \\
& 3 & $1.2^{\mathrm{c}, \mathrm{A}}$ & $5.5^{\mathrm{a}, \mathrm{B}}$ & $1.3^{\mathrm{c}, \mathrm{A}}$ & $3.2^{\mathrm{b}, \mathrm{B}}$ & $1.4^{\mathrm{c}, \mathrm{B}}$ & 0.23 \\
Bitter taste intensity & 6 & $1.7^{\mathrm{d}, \mathrm{A}}$ & $6.6^{\mathrm{a}, \mathrm{A}}$ & $1.8^{\mathrm{d}, \mathrm{A}}$ & $5.2^{\mathrm{b}, \mathrm{A}}$ & $2.9^{\mathrm{c}, \mathrm{A}}$ & 0.26 \\
\hline
\end{tabular}

${ }^{\mathrm{a}-\mathrm{d}}$ Means in the same row without common superscripts are different $(P \leq 0.05)$.

${ }^{\mathrm{A}, \mathrm{B}}$ Means in the same column without common subscripts are different $(P \leq 0.05)$.

${ }^{1}$ Mean of 3 replicates.

${ }^{2}$ Scored as $1=$ none, 5 = definite, and 9 = pronounced.

${ }^{3} \mathrm{RFC}=$ reduced-fat control made with a non-EPS-producing culture; RF-JFR = reduced-fat cheese made with the ropy culture Lactococcus lactis ssp. cremoris JFR1; UFC = reduced-fat control made from $1.2 \times$ UF milk and a non-EPS-producing culture; UF-JFR = reduced-fat cheese made from $1.2 \times$ UF milk and the ropy culture Lactococcus lactis ssp. cremoris JFR1; and FFC = full-fat control made with a non-EPS-producing culture. 


\section{ACKNOWLEDGMENTS}

This study was supported in part by South Dakota Agricultural Experiment Station. The authors would like to thank F. Halaweish for his help with HPLC and Chr. Hansen (Milwaukee, WI) for providing starter culture.

\section{REFERENCES}

Acharya, M. R., and V. V. Mistry. 2004. Comparison of effect of vacuumcondensed and ultrafiltered milk on Cheddar cheese. J. Dairy Sci. 87:4004-4012.

AOAC. 2003. Official Methods of Analysis. 17th ed. AOAC, Gaithersburg, MD.

Ardö, Y. 1999. Evaluating proteolysis by analyzing the N content of cheese fractions. Bull. Int. Dairy Fed. 337:4-9.

Awad, S., A. N. Hassan, and F. Halaweish. 2005a. Application of exopolysaccharide-producing cultures in reduced fat Cheddar cheese: Composition and proteolysis. J. Dairy Sci. 88:4195-4203.

Awad, S., A. N. Hassan, and K. Muthukumarappan. 2005b. Application of exopolysaccharide-producing cultures in reduced fat Cheddar cheese: Texture and melting properties. J. Dairy Sci. 88:42044213.

Banks, J. M. 2004. The technology of low-fat cheese manufacture. J. Soc. Dairy Technol. 57:199-207.

Creamer, L. K., M. Iyer, and J. Lelievre. 1987. Effect of various levels of rennet addition on characteristics of Cheddar cheese made from ultrafiltered milk. N.Z. J. Dairy Sci. Technol. 22:205-214.

Dabour, N., E. Kheadr, N. Benhamou, I. Fliss, and G. LaPointe. 2006. Improvement of texture and structure of reduced-fat Cheddar cheese by exopolysaccharide-producing lactococci. J. Dairy Sci. 89:95-110.

Farkye, N. Y. 1995. Contribution of milk-clotting enzymes and plasmin to cheese ripening. Pages 195-207 in Chemistry of Structure-Function Relationships in Cheese. E. L. Malin and M. H. Tunick, ed. Plenum Press, New York, NY.

Fenelon, M. A., and T. P. Guinee. 1999. The effect of milk fat on Cheddar cheese yield and its prediction, using modifications of the Van Slyke cheese yield formula. J. Dairy Sci. 82:2287-2299.

Fenelon, M. A., P. O'Connor, and T. P. Guinee. 2000. The effect of fat content on the microbiology and proteolysis in Cheddar cheese during ripening. J. Dairy Sci. 83:2173-2183.

Folkertsma, B., and P. F. Fox. 1992. Use of the cadmium-ninhydrin reagent to assess proteolysis in cheese during ripening. J. Dairy Res. 59:217-224.

Fox, P. F., and P. L. H. McSweeney. 1996. Proteolysis in cheese during ripening. Food Rev. Int. 12:457-509.

Green, M. L., F. A. Glover, E. M. W. Scurlock, R. J. Marshall, and D. A. Hatfield. 1981. Effect of use of milk concentrated by ultrafiltration on the manufacture and ripening of Cheddar cheese. J. Dairy Res. 48:333-341.

Green, M. L., and A. S. Grandison. 1993. Secondary (non-enzymatic) phase of rennet coagulation and post-coagulation phenomena. Pages 110-140 in Cheese: Chemistry, Physics and Microbiology. Vol. 1. 2nd ed. P. F. Fox, ed. Chapman and Hall Inc., London, UK.
Hassan, A. N., S. Awad, and K. Muthukumarappan. 2005. Effects of exopolysaccharide-producing cultures on the viscoelastic properties of reduced-fat Cheddar cheese. J. Dairy Sci. 88:4221-4227.

Hassan, A. N., J. F. Frank, and M. El-Soda. 2003. Observation of bacterial exopolysaccharide in dairy products using cryo-scanning electron microscopy. Int. Dairy J. 13:755-762.

Hassan, A. N., J. F. Frank, K. A. Schmidt, and S. I. Shalabi. 1996a. Rheological properties of yogurt made with encapsulated nonropy lactic cultures. J. Dairy Sci. 79:2091-2097.

Hassan, A. N., J. F. Frank, K. A. Schmidt, and S. I. Shalabi. 1996b. Textural properties of yogurt made with encapsulated nonropy lactic cultures. J. Dairy Sci. 79:2098-2103.

Hickey, M. W., H. V. Leeuwen, A. J. Hillier, and G. R. Jago. 1983. Amino acid accumulation in Cheddar cheese manufactured from normal and ultrafiltered milk. Aust. J. Dairy Technol. 38:110-113.

Johnson, M. E., C. M. Chen, and J. J. Jaeggi. 2001. Effect of rennet coagulation time on composition, yield, and quality of reduced-fat Cheddar cheese. J. Dairy Sci. 84:1027-1033.

Kosikowski, F. V. 1973. Cheesemaking by ultrafiltration. J. Dairy Sci. $57: 488-491$

Laws, A. P., and V. M. Marshall. 2001. The relevance of exopolysaccharides to the rheological properties in milk fermented with ropy strains of lactic acid bacteria. Int. Dairy J. 11:709-721.

Lelievre, J., and R. C. Lawrence. 1988. Manufacture of cheese from milk concentrated by ultrafiltration. J. Dairy Res. 55:465-478.

Lemieux, L., and R. E. Simard. 1992. Bitter flavor in dairy products. II. A review of bitter peptides from casein: Their formation, isolation and identification, structure masking and inhibition. Lait 72:335-382.

Marshall, R. J. 1982. An improved method for measurement of the syneresis of curd formed by rennet action on milk. J. Dairy Res. 49:329-336

McGregor, J. U., and C. H. White. 1990. Effect of enzyme treatment and ultrafiltration on the quality of lowfat Cheddar cheese. J. Dairy Sci. 73:571-578.

McSweeney, P. L. H., and P. F. Fox. 1993. Cheese: Methods of chemical analysis. Pages 341-388 in Cheese: Chemistry, Physics and Microbiology. Vol. 1. 2nd ed. P. F. Fox, ed. Chapman and Hall Inc., London, UK.

Mistry, V. V. 2001. Low fat cheese technology. Int. Dairy J. 11:413-422.

O'Keeffe, A. M., P. F. Fox, and C. Daly. 1978. Proteolysis in Cheddar cheese: Role of coagulant and starter bacteria. J. Dairy Res. 45:465-477.

Sallami, L., E. E. Kheadr, I. Fliss, and J. C. Vuillemard. 2004. Impact of autolytic, proteolytic, and nisin-producing adjunct cultures on biochemical and textural properties of Cheddar cheese. J. Dairy Sci. 87:1585-1594.

SAS Institute. 1999. User's Guide: Statistics. Version 8 ed. SAS Inst. Inc., Cary, NC.

Shannon, C. 1987. Ultrafiltration and its applications in cheese manufacture. Cult. Dairy Prod. J. 22:23-26.

Spangler, P. L., L. A. Jensen, C. H. Amundson, N. F. Olson, and C. G. Hill. 1990. Gouda cheese made from ultrafiltered milk: Effects of concentration factor, rennet concentration, and coagulation temperature. J. Dairy Sci. 73:1420-1428.

USDA. 1993. Agricultural marketing service: Dairy division. USDA Specifications for Reduced Fat Cheddar Cheese. http://www.ams.usda.gov/dairy/fatchedr.pdf

Visser, F. 1993. Proteolytic enzymes and their relation to cheese ripening and flavor: An overview. J. Dairy Sci. 76:329-350. 